\title{
KAITAN ANTARA OBESITAS DAN AKTIVITAS FISIK
}

\author{
Oleh: Fathan Nurcahyo \\ Dosen Jurusan Pendidikan Olahraga FIK UNY
}

\begin{abstract}
Abstrak
Obesitas merupakan suatu keadaan di mana berat badan seseorang berada di atas $120 \%$ dari berat badan relatif (BBR) atau berada di atas 27 dari indeks masa tubuh (IMT). Dewasa ini,insidensi obesitas anak semakin mengalami peningkatan. Hal ini membawa dampak yang kurang menguntungkan. Anak yang mengalami kegemukan cenderung malas bergerak dan beraktivitas jasmani sehingga pengalaman motorik, keterampilan motorik serta kebugaran jasmaninya menjadi terbatas dan kurang berkembang.

Untuk mencegah terjadinya kegemukan maka sangat disarankan untuk melakukan olahraga secara teratur, mengatur menu dan porsi makan, minum dan makan yang berserat untuk melancarkan pencernaan. Apabila kegemukan sudah terjadi, harus dilakukan balance energe negatif dengan melakukan diet (mengurangi porsi makan) serta peningkatan aktivitas fisik.
\end{abstract}

Kata Kunci: kegemukan, aktivitas jasmani Anak

Pada era globalisasi ini, tidak bisa dipungkiri bahwa perkembangan dan kemajuan ilmu pengetahuan dan teknologi banyak sekali berpengaruh terhadap diri dan lingkungan di sekitar. Kemajuan ilmu pengetahuan dan tekhnologi diberbagai bidang memberikan dampak yang positif dan negatif bagi seseorang. Salah satu contoh dampak negatif dari kemajuan ilmu pengetahuan dan teknologi adalah banyaknya aktivitas manusia yang digantikan peranannya oleh sebuah mesin atau robot yang berakibat pada menurunnya mobilitas gerak manusia dan tingkat kebugaran jasmani seseorang.

Kompleksnya tingkat kepentingan dan kebutuhan manusia yang tidak terbatas saat ini memaksa bagi setiap orang untuk selalu bekerja tanpa henti, sehingga kurang memperhatikan waktu istirahat, aktivitas jasmani dan rekreasi serta menu dan pola makan yang sehat dan higienis, terlebih kebanyakan orang tua atau keluarga karier. Orangtua atau keluarga karier kebanyakan hanya berpikir bahwa apabila anak-anaknya banyak 
atau lahap makan dan terpenuhi gizinya sehingga terlihat gemuk yang berarti bahwa tubuhnya sehat dan kuat. Orangtua atau keluarga karier kebanyakan tidak berpikir bahwa selain adanya faktor keturunan (genetika), penumpukan gizi dan energi di dalam tubuh dalam jangka waktu yang lama juga dapat menyebabkan terjadinya kegemukan atau obesitas apabila tidak diimbangi dengan aktivitas jasmani atau rekreasi. Sesungguhnya tubuh yang gemuk kurang baik bagi kesehatan, baik bagi orang dewasa maupun bagi anak-anak, karena pada tubuh yang gemuk biasanya mudah terserang penyakit (mudah sakit dan tidak bugar).

Anak-anak yang memiliki berat tubuh yang berlebihan atau mengalami kegemukan (obesitas) biasanya sering diejek atau dicemooh oleh teman-temannya sehingga anak tersebut menjadi anak yang pemalu, cenderung manja dan malas-malasan. Anak yang mengalami obesitas biasanya memiliki kebiasaan ngemil yang tinggi (makan-makanan ringan), banyak menyendiri, banyak berdiam diri di kamar/di rumah, mudah dan lebih banyak tidur, sehingga kurang atau bahkan tidak suka beraktivitas jasmani dan berolahraga (fisik). Anak yang mengalami obesitas biasanya di rumah lebih menyukai permainan game fantasi (play station). Dengan jarang bergerak atau beraktifitas jasmani maka anak akan kurang bugar, pengalaman dan tingkat ketrampilan geraknya juga kurang, baik gerak lokomotor, nonlokomotor, maupun manipulatif. Anak yang mengalami obesitas selain ketrampilan geraknya akan cenderung kaku, tidak lincah, dan juga mudah terserang penyakit karena daya tahan fisiknya juga kurang baik, tetapi biasanya juga memiliki kelebihan pada keseimbangan tubuh yang relatif baik. Sebagai akibat lebih lanjut dari keadaan tersebut dapat mengakibatkan anak terhambat dalam melaksanakan aktivitas fisik. Tulisan ini akan membahas tentang hubungan antara obesitas dengan aktivitas fisik.

\section{DEFINISI DAN KRITERIA OBESITAS}

Obesitas adalah suatu keadaan yang melebihi dari berat badan relative seseorang, sebagai akibat penumpukan zat gizi terutama karbohidrat, protein dan lemak. Kondisi tersebut disebabkan oleh ketidakseimbangan antara konsumsi energi dan kebutuhan energi, yaitu konsumsi makanan (yang terlalu banyak) dibandingkan dengan kebutuhan atau pemakaian energi (yang lebih sedikit), (Budiyanto, 2002: 7). Menurut pendapat Budiyanto (2002: 10), Untuk menentukan obesitas diperlukan kriteria yang berdasarkan pengukuran antropometri dan atau pemeriksaan laboratorik, pada umumnya digunakan:

1. Pengukuran berat badan (BB) yang dibandingkan dengan standar dan disebut obesitas bilamana BB > $120 \%$ BB standar.

2. Pengukuran berat badan dibandingkan tinggi badan (BB/TB). Dikatakan obesitas bila $\mathrm{BB} / \mathrm{TB}>$ persentile ke 95 atau $>120 \%$ atau Z-score $=+2 \mathrm{SD}$.

3. Pengukuran lemak subkutan dengan mengukur skinfold thickness (tebal lipatan kulit/TLK). 
4. Sebagai indikator obesitas bila TLK Triceps $>$ persentil ke 85 .

5. Pengukuran lemak secara laboratorik, misalnya densitometri, hidrometri dsb. yang tidak digunakan pada anak karena sulit dan tidak praktis. DXA adalah metode yang paling akurat, tetapi tidak praktis untuk di lapangan.

6. Indeks Massa Tubuh (IMT) $>27,0 / \mathrm{kg} / \mathrm{m}^{2}$.

Lebih lanjut menurut pendapat yang dikemukakan oleh Akhmadi (2010: 1-2), berat badan (BB) yang ideal bagi seseorang dapat dirumuskan sebagai berikut:

1. Berat Badan Relatif (BBR)

Berat Badan (kg) X $100 \%$

Tinggi Badan $(\mathrm{cm})-100$

Nilai Standar:
a. $<90 \%=$ Underweight
b. $\quad 90-100 \%=$ Berat Normal
c. $>110 \%=$ Overweight
d. $>120 \% \quad$ = Obesitas $/$ Gemuk

2. Indeks Masa Tubuh (IMT)

Berat Badan (kg) $=$

Tinggi Badan X Berat Badan (m2)

Nilai Standar:
a. $\quad<18,5=$ maka dapat dikatakan IMT Kurang
b. $\quad 18,5-25=$ maka dapat dikatakan IMT Normal
c. $25-27=$ maka dapat dikatakan IMT Lebih
d. $\quad>27=$ maka dapat dikatakan sebagai Obesitas atau Kegemukan

Berdasarkan uraian di atas maka dapat disimpulkan bahwa, kegemukan (obesitas) adalah suatu keadaan di mana berat badan seseorang berada di atas $120 \%$ dari berat badan relatif (BBR) atau berada di atas 27 dari indeks masa tubuh (IMT).

\section{FAKTOR-FAKTOR PENYEBAB TERJADINYA OBESITAS}

Penyebab terjadinya obesitas belum diketahui secara pasti. Obesitas adalah suatu penyakit multifaktorial yang diduga bahwa sebagian besar obesitas disebabkan karena interaksi antara faktor genetik dan faktor lingkungan. Adapun faktor-faktor tersebut antara lain meliputi: aktivitas, gaya hidup, sosial ekonomi dan nutrisional, yaitu perilaku makan dan pemberian makanan padat yang terlalu dini diberikan pada bayi.

\section{Faktor Genetik}

Apabila kedua orang tua obesitas, $80 \%$ anaknya akan menjadi obesitas. Apabila salah satu orang tuanya obesitas, kejadian obesitas menjadi $40 \%$ dan 
bila kedua orang tua tidak obesitas, maka prevalensinya menjadi $14 \%$. Kegemukan dapat diturunkan dari generasi sebelumnya kepada generasi berikutnya di dalam sebuah keluarga. Itulah sebabnya seringkali dijumpai orangtua yang gemuk cenderung memiliki anak-anak yang gemuk pula. Dalam hal ini tampaknya faktor genetik telah ikut campur dalam menentukan jumlah unsur sel lemak dalam tubuh seseorang. Hal ini dimungkinkan karena pada saat ibu yang obesitas sedang hamil maka unsur sel lemak yang berjumlah besar dan melebihi ukuran normal, secara otomatis akan diturunkan kepada sang bayi selama dalam kandungan. Tidaklah mengherankan apabila bayi yang dilahirkannya pun memiliki unsur lemak tubuh yang relatif sama besar.

Selain itu pengaruh keturunan (genetik) juga dapat berdampak pada komposisi/ bentuk tubuh. Menurut pendapat Erminawati (2009: 8), manusia memiliki tiga bentuk tipe tubuh yaitu:

a. Mesomorp (atletis), yaitu tipe tubuh yang memiliki ciri-ciri: tubuh tinggi, bahu yang lebar, pinggang yang relatif kecil, bentuk kepala yang persegi, dan perkembangan otot yang lebih besar.

b. Ektomorp (tubuh kurus dan tinggi), yaitu tipe tubuh yang memiliki ciri-ciri: tubuhnya tinggi, badan kurus, cepat merasa kedinginan, permukaan kulit yang relatif luas dibandingkan dengan volume tubuhnya.

c. Endomorph (tubuh bulat dan pendek), yaitu tipe tubuh yang memiliki ciriciri: bentuk tubuhnya bulat dan gemuk, volume batang tubuhnya relatif lebih besar, mempunyai usus kurang lebih $60 \mathrm{~cm}$, dua kali lebih panjang daripada umumnya.

\section{Faktor Lingkungan}

\section{a. Aktivitas Fisik}

Penelitian di negara maju menunjukkan bahwa terdapat hubungan antara aktivitas fisik yang rendah dengan kejadian obesitas. Individu dengan aktivitas fisik yang rendah mempunyai risiko peningkatan berat badan lebih besar dari pada orag yang aktif berolahraga secara teratur. Kurangnya aktivitas fisik kemungkinan merupakan salah satu penyebab utama dari meningkatnya angka kejadian obesitas di tengah-tengah masyarakat yang makmur. Orang-orang yang tidak aktif memerlukan lebih sedikit energi. Seseorang yang cenderung mengkonsumsi makanan kaya lemak dan tidak melakukan aktivitas fisik yang seimbang, akan mengalami obesitas.

b. Faktor Nutrisional dan Gizi

Peranan faktor nutrisi dimulai sejak dalam kandungan di mana jumlah lemak tubuh dan pertumbuhan bayi dipengaruhi oleh berat badan ibu. Kenaikan berat badan dan lemak anak dipengaruhi oleh: waktu pertama kali mendapat makanan padat, asupan tinggi kalori dari karbohidrat dan lemak serta kebiasaan mengkonsumsi makanan yang mengandung energi tinggi. 
Mengkonsumsi minuman ringan (soft drink) terbukti memiliki kandungan gula yang tinggi sehingga berat badan akan cepat bertambah bila mengkonsumsi minuman ini. Rasa yang nikmat dan menyegarkan menjadikan anak-anak sangat menggemari minuman ini. Selain itu mengkomsumsi makanan cepat saji, daging dan makanan berlemak akan meningkatkan risiko terjadinya obesitas menjadi lebih besar, Keadaan ini disebabkan karena makanan berlemak mempunyai energy density lebih besar dan lebih tidak mengenyangkan serta mempunyai efek termogenesis yang lebih kecil dibandingkan makanan yang banyak mengandung protein dan karbohidrat. Makanan berlemak juga mempunyai rasa yang lezat sehingga akan meningkatkan selera makan yang akhirnya terjadi konsumsi yang berlebihan. Apabila cadangan lemak tubuh rendah dan asupan karbohidrat berlebihan, maka kelebihan energi dari karbohidrat sekitar 60-80\% disimpan dalam bentuk lemak tubuh. Lemak mempunyai kapasitas penyimpanan yang tidak terbatas.

\section{Faktor Sosial Ekonomi dan Gaya Hidup}

Perubahan pengetahuan, sikap, perilaku dan gaya hidup, pola makan, serta peningkatan pendapatan mempengaruhi pemilihan jenis dan jumlah makanan yang dikonsumsi. Dalam beberapa tahun terakhir menunjukkan bahwa telah terlihat adanya perubahan gaya hidup yang menjurus pada penurunan aktivitas fisik, seperti: berangkat kerja atau ke sekolah dengan naik kendaraan dan kurangnya aktivitas bermain/berolahraga dan berekreasi dengan teman serta lingkungan rumah atau yang tidak memungkinkan anak-anak bermain di luar rumah, menyebabkan anak lebih senang bermain komputer/games, play station, nonton TV atau video dibanding melakukan aktivitas fisik atau olahraga. Selain itu juga meningkatnya jumlah pendapatan dan perubahan status sosial ekonomi serta gaya hidup modern serta ketersediaan dan harga dari makanan junk food (makanan cepat saji) yang mudah di dapat dan terjangkau harganya akan berisiko menimbulkan terjadinya obesitas menjadi lebih tinggi.

\section{DAMPAK TERJADINYA OBESITAS}

Menurut Budiyanto (2002: 22), kegemukan (obesitas) dapat menimbulkan terjadinya berbagai macam jenis penyakit yang serius, antara lain:

1. Diabetes militus (DM).

2. Hipertensi (darah tinggi) dan stroke.

3. Ganguan ortopedik.

4. Jantung.

5. Coronary artery disease.

6. Ginjal.

7. Gallbladder disorders dan bahkan risiko kematian. 


\section{KAITAN ANTARA OBESITAS DAN AKTIVITAS FISIK PADA ANAK}

Bergerak dan bermain bagi anak-anak terutama yang masih berusia dini merupakan sebuah pekerjaan dan menjadi kebutuhan paling utama dalam kehidupannya. Pertumbuhan dan perkembangan gerak dasar sangat identik dengan domain ranah psikomotorik dari aspek jasmaniah yang memberikan sumbangan yang sangat besar terhadap perkembangan ranah kognitif (kecerdasan intelektual/IQ) dan ranah afektif (sikap). Konsep gerak dasar sangat erat hubungannya dengan ketrampilan yang harus dimiliki atau dikuasai oleh anakanak sebagai dasar untuk melakukan aktivitas yang lebih rumit dan kompleks.

Aktivitas jasmani adalah segala bentuk gerak yang dilakukan oleh manusia yang menggunakan atau melibatkan sekelompok otot tertentu untuk mencapai tujuan tertentu, (J. Matakupan, 1995: 32). Melalui aktivitas jasmani yang dilakukan oleh seorang anak, anak akan mendapatkan banyak pengalaman gerak, kebugaran jasmani, mengenal jati diri dan lingkungannya. Selain itu melalui gerak atau aktivitas jasmani yang dilakukan oleh anak juga dapat memberikan manfaat lain, yaitu untuk mencegah terjadinya kegemukan (obesitas). Anak yang malas bergerak atau beraktivitas jasmani akan cenderung lebih cepat mengalami kegemukan. Bermain atau beraktivitas jasmani selain untuk rekreasi dan menyalurkan hobi, beraktivitas jasmani juga dapat digunakan sebagai sarana untuk menyalurkan kelebihan energi, meningkatkan pengalaman gerak dan memperhalus keterampilan atau teknik selain itu juga dapat membakar timbunan lemak dalam tubuh.

Masa kanak-kanak adalah masa yang paling krusial dalam proses tumbuh kembangnya, baik secara fisik, psikis maupun sosial. Anak harus dilatih dan berikan banyak pengalaman dan penguasaan gerak dasar yang bermanfaat bagi dirinya di masa yang akan datang. Pengalaman dan penguasaan gerak yang dikuasai oleh anak sejak masa kanak-kanak akan dibawanya ketahap selanjutnya untuk berkompetisi dan mempertahankan hidup. Pengalaman atau penguasaan gerak dapat diperoleh anak melalui orangtua, guru, pelatih, teman atau lingkungan (secara otodidak). Orangtua atau keluarga merupakan pelaku awal yang terbaik yang memberikan, mengajarkan dan melatihkan banyak pengalaman dan penguasaan gerak sebagai pondasi atau dasar gerak selanjutnya. Seorang anak yang malas bergerak atau beraktivitas jasmani akan beresiko/rentan terhadap kegemukan begitu juga sebaliknya anak yang mengalami kegemukan juga cenderung malas bergerak/ beraktivitas jasmani. Anak yang mengalami kegemukan akan cenderung malas beraktivitas jasmani/bergerak (manja) sehingga dapat berakibat pada kurangnya pengalaman gerak, tingkat penguasaan keterampilan gerak dasarnya menjadi terhambat dan juga tingkat kebugaran jasmaninya akan relatif kurang baik. 
a

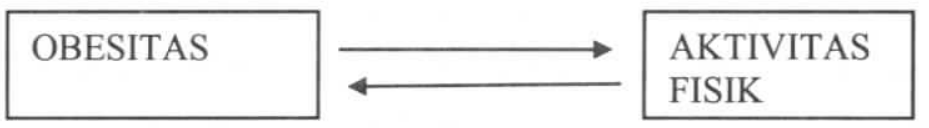

b

Gambar 1. Ilustrasi Keterkaitan antara Obesitas dan Aktivitas Fisik

a. Obesitas dapat mengurangi tingkat aktivitas serta kebugaran fisik

b. Rendahnya level aktivitas fisik dapat menimbulkan obesitas

Gerak atau aktivitas jasmani yang disarankan untuk menjaga kebugaran jasmani bagi anak adalah minimal tiga kali dalam satu minggu dengan durasi waktu 60-90 menit dengan intensitas sedang. Melalui aktivitas jasmani yang terukur ini diharapkan dapat membantu menjaga kebugaran jasmani dan membantu penyaluran tenaga serta pembakaran lemak sehingga dapat mencegah terjadinya kegemukan, (Djoko Pekik Irianto: 2000: 22).

\section{AKTIVITAS FISIK SEBAGAI BAGIAN DARI PENANGANAN OBESITAS}

Apabila seorang anak sudah mengalami kegemukan (obesitas), tingkat penguasaan ketrampilan gerak dasarnya secara otomatis akan menjadi terhambat dan juga tingkat kebugaran jasmaninya akan relatif menurun atau kurang baik. Untuk mencegah terjadinya kegemukan (obesitas) sangat disarankan untuk:

1. Melakukan Olahraga dan Rekreasi secara Teratur

Olahraga merupakan salah satu bagian program penurunan berat badan. Olahraga yang dilakukan dengan tepat, teratur, dan terukur dapat memberikan peningkatan pengeluaran energi yang cukup besar untuk menjaga atau menurunkan berat badan secara berkala. Selain itu olahraga yang teratur dapat menjaga dan meningkatkan daya tahan tubuh atau kebugaran jasmani dan menghindarkan atau meminimalisasi dari berbagai serangan penyakit.

2. Mengatur Menu, Pola, dan Porsi Makan

Mengurangi mengkonsumsi makanan cepat saji atau fast food, makanan ringan dalam kemasan, minuman ringan, cemilan manis atau makanan dengan kandungan lemak tinggi. Sebaliknya, sajikan daging dan sayuran segar. Perbanyak konsumsi buah, susu, dan makan yang berserat untuk melancarkan pencernaan dan yang baik pula untuk pertumbuhan anak. Berikan porsi yang sesuai dan jangan terlalu berlebihan. Sarapan merupakan awal yang baik untuk anak saat memulai harinya. Ini diperlukan agar anak dapat kuat saat beraktivitas di sekolah dan mencegah makan berlebihan setelahnya. Dengan membawa makanan dari rumah, orang-tua dapat mengontrol 
gizi anak dan menghindari agar anak tidak perlu jajan di luar. Jangan terlalu banyak menggoreng makanan agar tidak terlalu banyak lemak yang dikonsumsi. sebaiknya mencoba untuk mengukus, merebus atau memanggang makanan agar makanan lebih sehat. Biasakan agar anak makan di meja makan bukan di depan televisi atau komputer. Banyak anak tidak menyadari berapa banyak makanan yang sudah disantapnya apabila dia makan sambil menikmati tayangan televisi atau di depan komputer.

3. Diet

Apabila sudah terjadi kelebihan berat badan atau mungkin kegemukan maka disarankan untuk melakukan diet (mengurangi porsi makan). Menurut pendapat Budiyanto (2002: 22), diet adalah mengurangi kandungan energinya di bawah kebutuhan normal, cukup vitamin dan mineral serta banyak mengandung serat yang bermanfaat dalam proses penurunan berat badan. Diet ini membatasi makanan padat energi, seperti kue-kue yang banyak mengandung karbohidrat sederhana dan lemak, serta goreng-gorengan. Menurut pendapat Budiyanto (2002: 25), tujuan diet energi rendah adalah untuk:

a. Mencapai dan mempertahankan status gizi sesuai dengan umur, gender, dan kebutuhan fisik.

b. Mencapai IMT normal yaitu $18,5-25 \mathrm{~kg} / \mathrm{m}^{2}$.

c. Mengurangi asupan energi, sehingga tercapai penurunan berat badan sebanyak 0,5-1 kg/minggu. Pastikan bahwa yang berkurang adalah lemak dengan mengukur tebal lemak lipatan kulit dan lingkar pinggang.

4. Terapi dan Obat-Obatan

Terapi obesitas adalah terapi yang bertujuan untuk mengurangi asupan makanan yang mengganggu metabolisme tubuh dengan cara mempengaruhi proses pra atau pasca absorbsi. Terapi ini berusaha untuk menambah dan meningkatkan pengeluaran sistem energi (termogenesis) yang dimanfaatkan oleh tubuh untuk beraktivitas jasmani, (www.depkes.go.id/index.php):

a. Efedrin: meningkatkan pengeluaran energi, akan meningkatkan konsumsi oksigen sekitar $10 \%$ selama beberapa jam. Pada uji klinis efedrin dan kafein menghasilkan penurunan berat badan lebih besar dibanding kelompok plasebo. Diperkirakan 25-40\% penurunan berat badan oleh karena termogenesis dan 60-75 \% karena pengurangan asupan makanan. Efek samping utama adalah peningkatan nadi dan perasaan yang berdebar-debar.

b. Sibutramin: menurunkan energy intake dan mempertahankan penurunan pengeluaran energi setelah penurunan berat badan. Pada penelitian ternyata terbukti sibutramin menurunkan asupan makanan dengan cara mempercepat timbulnya rasa kenyang dan mempertahankan penurunan pengeluaran energi setelah penurunan berat badan, 
c. Obat yang mengurangi nafsu makan terdiri atas noradrenergic agent (benzphetamine, phendimetrazine, phentermine, phentermineresin, dietbylpropion), serotonin agent, dan kombinasi keduanya (sibutramine). Obat ini bekerja dengan menekan neurotransmitter seperti norepinephrine, serotonin, dopamine, dll di susunan saraf pusat yang berperan dalam meningkatkan nafsu makan. Obat ini hanya dapat dikonsumsi selama 12 minggu hingga 6 bulan. Efek samping yang mungkin timbul adalah insomnia, mulut kering, konstipasi, sakit kepala, euforia, palpitasi dan bipertensi.

d. Obat yang mengurangi absorbsi makanan di usus yaitu orlistat. Obat ini bekerja dengan mengikat lipase yang merupakan enzim yang berperan dalam mempermudah absorbsi lemak di usus, sehingga akhirnya lemak tidak bisa diserap. Obat ini dapat digunakan dalam jangka panjang dan efek samping yang dapat timbul adalah buang gas disertai kotoran, sulit menahan BAB, steatorrhea, bercak minyak di celana dalam, frekuensi BAB meningkat, dan kekurangan vitamin yang larut dalam lemak (A,D, E, K) tetapi bisa diatasi dengan suplemen dari luar.

5. Pembedahan

Pembedahan atau sering disebut dengan istilah sedot lemak merupakan pilihan alternatif terakhir untuk menurunkan berat badan apabila dari berbagai usaha-usaha di atas gagal atau minim hasilnya. Pembedahan dan sedot lemak sebaiknya dilakukan oleh seorang dokter atau orang yang benar-benar ahli agar tidak terjadi kesalahan atau mal praktik yang dapat berujung pada kematian pasien.

\section{KESIMPULAN}

Insidensi obesitas pada anak dewasa ini semakin mengalami peningkatan. Anakanak yang memiliki berat tubuh yang berlebihan atau mengalami kegemukan (obesitas) cenderung manja dan malas-malasan dalam beraktifitas jasmani dan berolahraga (fisik). Akibat dari keadaan tersebut dapat menyebabkan pertumbuhan fisik motorik anak menjadi tidak optimal. Anak yang telah mengalami obesitas dianjurkan untuk mengatur balance energy negative dan energi yang dikeluarkan sebaiknya melebihi asupan energi dari makanan. Melalui aktivitas jasmani yang dilakukan, anak akan mendapatkan banyak pengalaman gerak, kebugaran jasmani, mengenal jati diri dan lingkungannya. Selain itu melalui gerak atau aktivitas jasmani juga dapat memberikan manfaat lain, yaitu untuk mencegah terjadinya kegemukan (obesitas). Anak yang malas bergerak atau beraktivitas jasmani akan cenderung lebih cepat mengalami kegemukan. Bermain atau beraktivitas jasmani selain untuk rekreasi dan menyalurkan hobi, beraktivitas jasmani juga dapat digunakan sebagai sarana untuk menyalurkan kelebihan energi dan membakar timbunan lemak dalam tubuh. 


\section{DAFTAR PUSTAKA}

Akhmadi. (2010). Pendidikan dan Perilaku Kesehatan. Jakarta: PT Rineka Cipta.

Budiyanto. (2002). Obesitas dan Perkembangan Anak. Jakarta: Grafindo Persada.

Djoko Pekik Irianto. (2000). Panduan Latiban Kebugaran yang Efektif dan Aman. Yogyakarta: Lukmạn Offset.

Erminawati. (2009). Kebugaran dan Kesehatan. Jakarta: Ricardo.

J. Matakupan. (1995). Teori Bermain. Jakarta: Depdikbud, Universitas Terbuka.

Mutohir dan Gusril (2004). Olahraga Kesehatan: Jakarta: Depdiknas.

M. Furqon. H. (2002). Pembinaan olabraga usia dini. Surakarta: Pusat Penelitian dan Pengembangan Keolahragaan (Puslitbang-OR) Universitas Sebelas Maret, Surakarta.

Siti Partini S. (1995). Psikologi perkembangan. Yogyakarta: FIP-IKIP Yogyakarta.

http://www.depkes.go.id/index.php?option=news\&task=viewarticle\&sid=3328.

http://wapedia.mobi/id/Obesitas.

http://www.e-psikologi.com/epsi/artikel detail.asp?id=378.

http://www.kalbe.co.id/files/cdk/files/07 ObesitasPadaAnak.pdf/ 07 ObesitasPadaAnak.html.

http://www.analisadaily.com/index.php?option. 